\title{
TRAVEL HEALTH KNOWLEDGE AND PERCEPTION OF FOREIGN BACKPACKERS TRAVELING IN BALI
}

\author{
Ni Made Dian Kurniasari, ${ }^{1,2 *}$ Desak Nym. Widyanthini, ${ }^{1}$ I Ketut Hari Mulyawan, ${ }^{1}$ I Md. Ady \\ Wirawan ${ }^{1,2,3}$ \\ ${ }^{1}$ Department of Public Health and Preventive Medicine, Faculty of Medicine, Universitas Udayana, Jl. PB. \\ Sudirman Bali, 80232 Indonesia \\ ${ }^{2}$ Travel Medicine Research Group, Health Research Centre, Institute for Research and Community Services \\ Universitas Udayana, Jalan Raya Kampus UNUD Bukit Jimbaran Bali, 80361, Indonesia \\ ${ }^{3}$ Centre of Excellence in Tourism, Universitas Udayana, Jalan Raya Kampus UNUD Bukit Jimbaran Bali, \\ 80361, Indonesia
}

\begin{abstract}
International travel to a country has potentially carry health risks for travelers, including backpackers. To date, little is known about Travel Health knowledge and perception among foreign backpackers traveling to Bali. This study aimed to explore the level of knowledge and perception, as well as health information that backpackers need in their destination, Bali. This was a descriptive cross-sectional study, conducted from December 2017 to January 2018 in Bali. This study involved 133 backpackers, taken by convenience sampling technique. Data were collected using a self-administered questionnaire and were analysed descriptively. The results showed that backpackers' knowledge was inadequate, especially to common diseases or health problems that occurred to travelers in Bali. There were $94.74 \%$ have low knowledge about rabies, $48.87 \%$ have less knowledge about methanol poisoning and $58.65 \%$ have low knowledge about diarrhoea. A total of $69.18 \%$ backpackers have a perception that they were not prone to being exposed to diseases and health problems in Bali and $36.84 \%$ were not aware that they had to seek health information before traveling to Bali. Almost all stated that they needed complete, destination-specific health information. It is necessary to increase backpackers' knowledge and awareness regarding Travel Health at the destination. The development of integrated health promotion media about travel health in Bali, in form of web-based or application-based is one of the strategies to consider.
\end{abstract}

Keywords: backpacke, knowledge, perception, travel-health risk.

\begin{abstract}
ABSTRAK
Perjalanan wisata internasional ke suatu negara berpotensi membawa risiko kesehatan bagi para wisatawan, termasuk backpacker. Sampai saat ini masih sedikit informasi yang diketahui tentang pengetahuan, persepsi, informasi yang dibutuhkan backpacker yang berkunjung ke Bali terkait kesehatan. Penelitian ini bertujuan untuk menggali tingkat pengetahuan dan persepsi, serta informasi kesehatan yang backpacker butuhkan di daerah tujuan, Bali. Penelitian ini merupakan penelitian cross-sectional deskriptif pada 133 sampel backpacker yang diambil secara convenience. Data dikumpulkan menggunakan kuisioner terstruktur yang diisi sendiri oleh responden dari bulan Desember 2017 hingga Januari 2018 di Provinsi Bali. Data dianalisis secara deskriptif. Hasil menunjukkan pengetahuan backpacker masih kurang khususnya tentang rabies (94,74\% kurang), keracunan alkohol oplosan (48,87\% kurang) dan diare (58,65\% kurang). Sebesar $69,18 \%$ backpacker merasa tidak rentan terpapar penyakit dan masalah kesehatan di Bali dan 36,84\% tidak sadar bahwa harus mencari informasi kesehatan sebelum bepergian ke Bali. Hampir semua menyatakan membutuhkan informasi kesehatan spesifik daerah tujuan yang lengkap. Dengan demikian, perlu upaya peningkatan pengetahuan dan kesadaran backpacker terkait kesehatan daerah tujuan. Pengembangan media promosi kesehatan yang terintegrasi, berbasis web atau aplikasi, oleh pemerintah terkait di Bali menjadi salah satu strategi yang bisa ditempuh.
\end{abstract}

Kata kunci: backpacker, pengetahuan, persepsi, risiko kesehatan wisata.

Correspondence Address: Ni Made Dian Kurniasari, Department of Public Health and Preventive Medicine, Faculty of Medicine, Universitas Udayana, Jl. PB. Sudirman Bali, Indonesia, E-mail: dian_kurniasari@unud.ac.id 


\section{Introduction}

Globally, International travels, include those for tourism purposes, have continued to increase every year within the last few decades. ${ }^{1}$ This increase has been occurred also in Indonesia, as one of the most popular tourist destinations in Asia Pacific. In 2011, there were 7,6 million foreign tourists who visited Indonesia, which increased to 10.2 million in 2015 and 11.5 million in $2016 .^{2}$ There were 4.9 million foreign tourists who entered Indonesia in 2016 came directly to Bali. $^{3}$

International travel will not only bring new experiences and expose travelers to new cultures, but it will also carry potential health risks for them. ${ }^{4,5}$ Individuals who travel may likely be exposed to hazards, contract or transmit infectious diseases, experience serious health problems due to tourism or travelling activities in the destination area. ${ }^{4}$ A study among travelers who traveled outside the Nordic countries found that there were $76 \%$ of travelers acquired illness during travel and $25 \%$ of them still had symptoms or showed new symptoms on arrival to two days after returning home. ${ }^{6}$ Three most common diseases reported were diarrhoea, skin problems and fever. A study conducted among Korean travelers discovered that there was an association between international travel to the increased cases of imported diseases, one of them was dengue, which some of The Korean travelers had a history of travel to Indonesia. ${ }^{7}$

The magnitude of health risks poses by travelers will depend on their characteristics and their travel. ${ }^{4}$ A trend of backpacker-style traveling, which is increasingly in demand, has a higher risk of experiencing health problems related to travel than that of other tourists. ${ }^{8}$ Backpacker is an individual who travels alone or in small groups, on a minimal budget, and commonly stay in cheap accommodation. ${ }^{8,9}$ The financial limitations make them less likely to pay attention about where to eat, what to eat, to choose accommodation with insufficient sanitation and being in unsafe environments; therefore they are more at risk of being infected with infectious diseases (i.e. diarrhoea, respiratory problems, malaria, sexually transmitted infections, etc.). ${ }^{4}$ In addition, they tend to drive alone, travel long distances to remote locations, undertake extreme adventurous tourism activities, so they are at a greater risk to experience accidents, getting bitten by wild animals and to expose by crime than other types of traveler. ${ }^{4}$

Health risks could be reduced by understanding the health problems at the destination country, so that travelers are able to prepare and practice healthy behaviours before or while traveling. However, based on many types of researches, there were still many tourists who did not seek health information and were not even aware of the potential exposure to infectious diseases in the destination country. ${ }^{10}$ In some cases, many travelers did not vaccinate prior to travel, although many pre-travel health services were accessible. ${ }^{11}$ 
Bali is a popular tourist destination in Indonesia, including to backpackers. ${ }^{5,12}$ Backpackers are potentially exposed to health risks, both from environmental factors or health behaviours, due to nature, culture and the lifestyle of people in Bali. Currently, there was little information about foreign backpackers' knowledge and awareness regarding the risks or health problems that might be experienced during and as a result of their travel in Bali. Moreover, from a previous study many backpackers were not aware of health information and how to seek health information. This is important to identify gaps in travel health and to improve health services at the destination. In accordance to the current pandemic situation that has affected tourism on so many levels where a lot has changed in response to Coronavirus Disease 2019 (COVID-19) precautions, including creating unpredicted gaps in travel health practices, one clear message is that COVID-19 has validated the importance of awareness towards infectious disease and travel health. ${ }^{13}$ Infectious diseases urge travel health consideration, as much as COVID-19, other infectious diseases endemic at the destination, as well as hazards and risks from tourism activities should also remain a concern as these affect the well-being of travelers. ${ }^{13}$ Although this research was conducted before the pandemic, the results of this study will still be relevant for reflection, because through understanding previous common travelers' behaviour, their knowledge and awareness to health risks specific in destination, their travel characteristics and needs will be useful in policymaking. Authorities may use such knowledge to formulate actions and provide services based on travelers needs, especially in response to the re-opening plan of tourism in near future. This study aimed to explore the level of knowledge and perceptions of health risks in Bali, as well as travel characteristics and travel health information they wish to have before or while in Bali.

\section{Method}

This was a cross-sectional study, conducted in popular locations of backpackers in Bali Province, which was in Badung Regency (i.e. Seminyak, Legian and Kuta area) and Gianyar Regency (i.e. Ubud and Batubulan area). Data were collected in December 2017 - January 2018 at the peak season of foreign visitors to Bali.

The study population was backpackers, defined with inclusion criteria of foreign travelers, aged 18 and above, who were able to understand spoken and written English, arranged travel independently without a travel agent, travelled on a restricted budget and stayed at a non-star lowcost accommodation (i.e. small hotels, guesthouses, and other low-cost hotels). This study focused on backpackers as a sample because this type of traveler was popular and yet they possed higher health risk than other types of traveler, due to their travel characteristics (i.e. tend to be younger, travel for a long time and in a limited budget, do more unassisted tourist activities, travel to remote areas, travel more often around destinations without being assisted by travel agents). The sample size was calculated using a cross-sectional survey sample size formula, with a proportion of good 
travel health knowledge among travelers from the previous study about $63.2 \%,{ }^{11} 10 \%$ precision and 95\% CI, the minimum sample given was 90. Finally, a total of 133 backpackers were included in this study, which is derived through a convenience sampling technique.

Trained enumerators approached potential respondents around tourism sites, culinary or local food court centres and low-budget hotels areas in study locations. Respondents were self-declared as backpackers, of those who traveled independently without a travel agent, with a restricted budget and staying at a low-cost non-star accommodation. Those who met inclusion criteria were invited to join the study. Respondents were provided with an information sheet, an informed consent and a questionnaire to complete and return to the trained enumerators. During data collection, trained enumerators were ready to facilitate if respondents needed further explanation.

The consented respondents were invited to complete a self-administered questionnaire designed to fill with less than 15 minutes. The authors conducted a thorough literature review in developing the questionnaire. Some questions and information from other previous similar studies were adopted and developed to construct the questionnaire items for this study. ${ }^{5}, 14$ The questionnaire was directly made in the English version, consisted of five sections. The first section was collecting backpackers' socio-demographic characteristics, such as age, sex, educational background, main job and country of residence. The second section gained information of their travel characteristics and pre-travel preparation including health-seeking behaviour before departure (i.e. time of visit to Bali, durations of stay, number of travel partners, durations to plan this trip, general and pre-travel health information seeking, pre-travel vaccination or medication, and source of information or health advice. The third part assessed backpackers' level of knowledge regarding the most common disease and health problems in Bali (i.e. rabies, dengue, diarhea, methanol poisoning and sexual transmitted infections), which consists of 12 questions ranging from the name of diseases, sources, transmission and preventive measures to undertake. They requested to respond to these questions by choosing the right answers as much as possible, each right answer was awarded with one mark to make a total score (0-18). The fourth part sought backpackers' perception towards travel health. The questions on perception were developed using health belief model theory; it measured the component of perceived susceptibility and severity of health risks, perceived benefits of and barrier to pre-travel health preventive actions and selfefficacy. The last part obtained backpackers' need of travel health information specific to destination country and where that information should be made available.

Data were analysed descriptively, presenting distribution of backpackers' characteristics, their level of knowledge, perception and travel health information needed by backpackers in Bali. Level of knowledge was classified into good $(\geq 75 \%$ correct answer, i.e. total score 13.5 and above) or poor $(<75 \%$ correct answer, i.e. total score of less than 13.5). Data were presented on tables. Descriptive statistics were performed by STATA version 12 . 
The research has received an ethical clearance from the Ethical Committee of Faculty of Medicine Udayana University and Sanglah General Hospital with letter No. 2683/UN.14.2/KEP/2017.

\section{Results}

\section{Socio-Demographic and Travel Characteristics}

The backpackers' median of age in this study was 38 years old and was ranged from 18-63 years old. Most of the backpackers (70.68\%) were $15-30$ years old and $30.8 \%$ were students.

Table 1. Socio-Demographic and Travel Characteristic of Backpackers

\begin{tabular}{|c|c|c|}
\hline Characteristics & $\mathrm{n}=\mathbf{1 3 3}$ & $\%$ \\
\hline \multicolumn{3}{|l|}{ Age (year) (median 28, range 18-63) } \\
\hline $15-30$ & 94 & 70.68 \\
\hline $31-45$ & 34 & 25.56 \\
\hline $46-60$ & 2 & 1.50 \\
\hline$>61$ & 3 & 2.26 \\
\hline \multicolumn{3}{|l|}{ Sex } \\
\hline Male & 65 & 48.87 \\
\hline Female & 68 & 51.13 \\
\hline \multicolumn{3}{|l|}{ Education } \\
\hline High school & 32 & 24.06 \\
\hline Diploma & 28 & 21.05 \\
\hline University & 74 & 54.89 \\
\hline \multicolumn{3}{|l|}{ Main Occupation } \\
\hline Student & 41 & 30.83 \\
\hline Government officer & 6 & 4.51 \\
\hline Private officer & 23 & 17.29 \\
\hline Part time worker & 24 & 18.05 \\
\hline Others & 39 & 29.32 \\
\hline \multicolumn{3}{|c|}{ Country of Origin (same to their pasport) } \\
\hline US & 9 & 6.77 \\
\hline Canada & 5 & 3.76 \\
\hline England & 12 & 9.02 \\
\hline Europe & 73 & 54.89 \\
\hline Asia & 4 & 3.01 \\
\hline Russia & 7 & 5.26 \\
\hline Australia \& New Zealand & 22 & 16.54 \\
\hline Africa & 1 & 0.75 \\
\hline \multicolumn{3}{|l|}{ Frequency of visit to Bali } \\
\hline First time & 73 & 54.89 \\
\hline 2-3 times & 40 & 30.08 \\
\hline 4 times or more & 20 & 15.03 \\
\hline \multicolumn{3}{|l|}{ Length of stay in Bali so far (week) } \\
\hline$\leq 1$ week & 14 & 10.53 \\
\hline $1-2$ weeks & 37 & 27.82 \\
\hline 3-4 weeks & 49 & 36.84 \\
\hline$>4$ weeks & 33 & 24.81 \\
\hline \multicolumn{3}{|l|}{ Number of traveling partner(s) } \\
\hline Travel alone & 19 & 14.29 \\
\hline $1-4$ friend(s) & 107 & 80.45 \\
\hline 5-10 friends & 6 & 4.51 \\
\hline$>10$ friends & 1 & 0.75 \\
\hline
\end{tabular}


There were no much differences between the number of female and male backpackers. Most of them (54.89\%) came from Europe, and then followed by Australia and New Zealand (16.54\%). A total of $54.89 \%$ of backpackers said this was their first time visit to Bali. There were about twothird of backpackers have been staying in Bali for more than 2 weeks (36.84\% stayed for 3-4 weeks and $24.81 \%$ stayed more than 4 weeks). The vast majority of backpackers $(80.45 \%)$ visited Bali with a small group of friends (1-4 people) (Table 1).

\section{Pre-travel Preparation}

Based on data in Table 2, a total of $46.62 \%$ backpackers planned their trip one month before departure and $13.53 \%$ for more than one month. There were some backpackers (17.30\%) who planned the trip two weeks prior to departure; $13.53 \%$ even just planned their tour after arrival in Bali. As many as $78.20 \%$ have sought general information related to tourism in Bali, which $85.58 \%$ sourced from the internet and $60.58 \%$ from family/friends. There were $62.41 \%$ who seek pre-travel health information, and it was obtained mostly from the internet (66.27\%). Only 32.33\% received vaccines or preventive medications before leaving for Bali.

Table 2. Pre-travel Characteristics of Backpackers

\begin{tabular}{lcc}
\hline Pre-travel Characteristics & $\mathbf{n}=\mathbf{1 3 3}$ & $\mathbf{\%}$ \\
\hline Pre-travel preparation time & & \\
> 1 month before departure & 18 & 13.53 \\
1 month before departure & 62 & 46.62 \\
2-3 weeks before departure & 12 & 9.02 \\
1-2 weeks before departure & 23 & 17.30 \\
On arrival at the destination & 18 & 13.53 \\
Seeking general travel information & & \\
Yes & 104 & 78.20 \\
No & 29 & 21.80 \\
Source of general travel information (n=104)* & & \\
Family or friends & 63 & 60.58 \\
Internet & 89 & 85.58 \\
Travel Agent & 7 & 6.73 \\
Travel Book & 36 & 34.62 \\
Seeking pre-travel health information & & \\
Yes & 83 & 62.41 \\
No & 50 & 37.59 \\
Source of pre-travel health information (n=83)* & & \\
General practitioner & 30 & 36.14 \\
Pre-travel health clinic & 19 & 22.89 \\
Pharmacist & 11 & 13.25 \\
Government Health department & 21 & 25.30 \\
Internet & 55 & 66.27 \\
Insurance providers & 2 & 2.41 \\
Received pre-travel preventive medication/vaccination & & \\
Yes (vaccinated) & 43 & 32.33 \\
No & 90 & 67.67 \\
\hline *can answer more than one choice & & \\
& & \\
\hline & &
\end{tabular}




\section{Knowledge of Travel Health}

The backpackers' knowledge regarding travel health in Bali were assessed by asking their general knowledge about the kind of endemic, most common diseases and health problems that pose a threat to tourists in Bali such as rabies, dengue, diarhea, methanol poissoning and sexual transmitted infections. In addition, it also added questions about diseases sources of transmission and preventive actions to undertake. As much as $94.74 \%$ still had insufficient knowledge about rabies, $48.87 \%$ still have less knowledge for methanol poisoning and $40.60 \%$ have low knowledge related to o diarrhoea. Overall, there were $58.65 \%$ of backpackers have insufficient travel health knowledge specific to the destination country, Bali (Table 3).

Table 3. Backpackers Knowledge regarding Most Common Health Risks/Diseases and

Preventive Action at The Destination, Bali

\begin{tabular}{lcc}
\hline \multicolumn{1}{c}{ Knowledge Items (n=133) } & Good $(\geq \mathbf{7 5 \% )}$ & $\begin{array}{c}\text { Less }(<\mathbf{7 5 \% )} \\
(\mathbf{n , ~ \% )}\end{array}$ \\
\hline Knowledge related to rabies & $7(5.26)$ & $126(94.74)$ \\
Knowledge related to dengue fever & $114(85.71)$ & $19(14.29)$ \\
Knowledge related to diarrhea & $79(59.40)$ & $54(40.60)$ \\
Knowledge related to methanol poisoning & $68(51.13)$ & $65(48.87)$ \\
Knowledge related to sexual transmitted infections & $125(93.98)$ & $8(6.02)$ \\
Total Level of Knowledge & $55(41.35)$ & $78(58.65)$ \\
\hline
\end{tabular}

\section{Perception toward Travel Health}

Table 4 presents data on backpackers' perceptions regarding potential health risks in Bali and health precautions that should be pursued. Most backpackers were disagree $(51.13 \%)$ to strongly disagree $(18.05 \%)$ that they were prone to the risk of disease/health problems when traveling in Bali. However, 58.65\% agree and 19.55\% strongly agree that the health risks that existed in the destination areas could have a serious health impact so it is necessary to take preventive measures. More than half agreed to seek health information (62.41\%) and administer vaccines $(66.92 \%)$ before departure as strategies to prevent disease infections and to ensure safety during the trip. There were $36.84 \%$ backpackers did not aware that they had to seek health information or advice prior to their travel to Bali. In addition, $32.33 \%$ thought that it would cost quite a lot of money to get the medical advices or vaccinations. A number of $67.67 \%$ believe they would be able to seek health information prior to departure and $66.17 \%$ would be able to seek health information on arrival in Bali. 
Table 4. Backpackers' Perception toward Health Risk and Pre-Travel Health Prevention

\begin{tabular}{|c|c|c|c|c|}
\hline Perception component and items $(n=133)$ & $\begin{array}{l}\text { Strongly } \\
\text { disagree } \\
\text { n (\%) }\end{array}$ & $\begin{array}{l}\text { Disagree } \\
\text { n (\%) }\end{array}$ & Agree & $\begin{array}{l}\text { Strongly } \\
\text { Agree } \\
\text { n (\%) }\end{array}$ \\
\hline \multicolumn{5}{|l|}{ Perceived susceptibility } \\
\hline $\begin{array}{l}\text { I am worried I may expose to health risks or diseases } \\
\text { during this trip. }\end{array}$ & $24(18.05)$ & $68(51.13)$ & $38(28.57)$ & $3(2.26)$ \\
\hline \multicolumn{5}{|l|}{ Perceived severity } \\
\hline $\begin{array}{l}\text { I believed that the consequences of getting exposed to } \\
\text { health risks or diseases during this trip are significant } \\
\text { enough to try to avoid. }\end{array}$ & $4(3.01)$ & $25(18.80)$ & $78(58.65)$ & $26(19.55)$ \\
\hline \multicolumn{5}{|l|}{ Perceived benefits of pre-travel health prevention } \\
\hline $\begin{array}{l}\text { I believed that by seeking health information of } \\
\text { destination country prior to departure will prevent me } \\
\text { from exposure to health risks or diseases. }\end{array}$ & $1(0.75)$ & $14(10.53)$ & $89(66.92)$ & $29(21.80)$ \\
\hline $\begin{array}{l}\text { I believe that by taking preventive medications or getting } \\
\text { vaccinations prior to departure will prevent me from } \\
\text { exposure to health risks or diseases. }\end{array}$ & $1(0.75)$ & $13(9.77)$ & $83(62.41)$ & $36(27.07)$ \\
\hline \multicolumn{5}{|l|}{ Perceived barrier of pre-travel health prevention } \\
\hline $\begin{array}{l}\text { I am unaware that I need to get health information or } \\
\text { medical advice prior to departure to prevent myself form } \\
\text { being exposed to health risks or disease in the destination } \\
\text { country. }\end{array}$ & $28(21.05)$ & $49(36.84)$ & $49(36.84)$ & $7(5.26)$ \\
\hline $\begin{array}{l}\text { I didn't know where I could get the health information or } \\
\text { medical advice prior to departure. }\end{array}$ & $38(28.57)$ & $67(50.38)$ & $24(18.05)$ & $4(3.01)$ \\
\hline $\begin{array}{l}\text { I didn't have time to get health information or medical } \\
\text { advice prior to departure }\end{array}$ & $41(30.83)$ & $63(47.37)$ & $22(16.54)$ & $7(5.26)$ \\
\hline $\begin{array}{l}\text { It will cost me much money to get medical advice or } \\
\text { getting vaccinations prior to departure. }\end{array}$ & $20(15.04)$ & $60(45.11)$ & $43(32.33)$ & $10(7.52)$ \\
\hline \multicolumn{5}{|l|}{ Self-efficacy } \\
\hline $\begin{array}{l}\text { I am able to seek health information of destination } \\
\text { country prior to departure. }\end{array}$ & $3(2.26)$ & $12(9.02)$ & $90(67.67)$ & $28(21.05)$ \\
\hline $\begin{array}{l}\text { I am able to seek health information in the destination } \\
\text { country during the trip }\end{array}$ & $4(3.01)$ & $21(15.79)$ & $88(66.17)$ & $20(15.04)$ \\
\hline
\end{tabular}

\section{Information Needed}

As many as $98.50 \%$ of backpackers stated that it was important to have health information or advice. The information they needed included the types of diseases and common health problems in Bali (69.47\%), preventive measures (66.41\%) and the location of the nearest health facilities (68.70\%). Most of the backpackers (74.81\%) stated that the information should be made feasible, accessible and made available at the entrance gates of Bali (i.e. airport, harbors, and bus terminals) and the Bali tourism website (72.53\%) (Table 5). 
Tabel 5. Travel Health Information Needs at The Destination Country

\begin{tabular}{lcc}
\hline \multicolumn{1}{c}{ Travel Health Information Needs } & $\mathbf{n}=\mathbf{1 3 3}$ & $\mathbf{\%}$ \\
\hline $\begin{array}{l}\text { Health information needs regarding travel health at } \\
\text { destination country }\end{array}$ & 131 & \\
$\quad$ Yes, important & 2 & 98.50 \\
$\quad$ No need & & 1.50 \\
Types of travel health information (n=131)* & 91 & 69.47 \\
Common health issues in destination country & 72 & 54.96 \\
Diseases transmission & 87 & 66.41 \\
Preventive actions & 80 & 61.07 \\
First Aids & 90 & 68.70 \\
Location of the nearest health facilities & 76 & 58.02 \\
Name, address and phone number of emergency & & \\
services & & \\
Information be made available at (n=131)* & 98 & 74.81 \\
Airport, harbour, public transport station & 83 & 63.36 \\
Accommodation places & 95 & 72.52 \\
Website of tourism in destination country & 70 & 53.44 \\
Tourist information centres & 13 & 9.92 \\
Restaurants or food court centres & 12 & 9.16 \\
Shopping centres & 4 & 3.05 \\
Others
\end{tabular}

*can answer more than one choice.

\section{Discussion}

Backpackers' sex distribution in this study was comparable to that from previous study, ${ }^{8,15}$ where numbers of male and female backpackers were similar, especially common among backpackers from western countries, as in this current study most of them came from Europe. The backpackers' characteristics in this study were in accordance with the characteristics of backpackers in common; the majority were young, students, stayed for longer period of time and travelled with small groups of friends. ${ }^{9}{ }^{12}$ According to these characteristics, backpackers are at a greater chance to be exposed to health risks or experienced health problems than that of other tourists. ${ }^{16}$ A study in Thailand showed that $10.2 \%$ backpackers reported to have experienced health problems when travelling in average of 10 days of duration. ${ }^{15}$ Diarrhoea was the most common health problem. Longer duration of stay were found to increase the occurance of travel related diseases. Another study in Thailand found that $20.8 \%$ backpackers took part in one or more activity with a high HBV exposure risk. ${ }^{8}$

Making travel arrangements, including seeking health information or consultations prior to departure, can help prepare backpackers from health risks at their destination. ${ }^{17}$ Most of the backpackers in this study have prepared their trip for one month or more prior to departure and were looking for general information regarding trip plans in Bali, most of which came from the internet and family/friends. The results of this study were consistent with results of previous backpackers' study and similar to other types of travelers, ${ }^{8}$ where most of travelers prepared trip at least 15 days or more before leaving and information obtained from family and the internet. ${ }^{(11,18)}$ Ideally, planning and arranging travel to other countries should be made approximately 1 to 2 
months in advance. ${ }^{19}$ Thus, backpackers have sufficient time, including to take preventive measures, such as completing an optimal vaccination schedule or buying and taking preventative medicines. ${ }^{20}$

In this study, $62.41 \%$ of backpackers were looking for health information or advice before leaving for Bali. This result was slightly lower than results from research by Frew et.al, where $80.1 \%$ of backpackers seek health information before leaving. ${ }^{8}$; but no much difference from the research of Mansanguan, where $58.3 \%$ of backpackers seek health information before leaving. ${ }^{15}$ In this study, the internet is a popular source of information accessed by backpackers, which is consistent with the results of previous studies. ${ }^{8}$

Although many backpackers have made pre-travel preparations in sufficient time, gained general information and searched health information about destination area, their knowledge was still inadequate regarding most common health risks in Bali, such as rabies, the risk of methanol poissoning and diarrhea. These results are similar to studies in Italy, where most travelers have a low knowledge of the risks and health problems that often occur in destinations country. ${ }^{21}$ The characteristics of backpackers' trip, which more often explore the remote areas, have put them to be more prone of contracting rabid animals, ${ }^{4}$ due to the presence of stray dogs, bats and monkeys, ${ }^{22}$ moreover in Bali, rabies is endemic. ${ }^{23}$ In addition, traveling to places where hygiene and sanitation standards are lacking will increase the risk of developing diarrhoea. ${ }^{4}$ The alcohol consumption increased during traveling, and an alcohol poisoning (contains methanol) is also an health issue that need to be aware of by tourists in Bali. ${ }^{14}$ The low knowledge of backpackers possibly caused by the unavailability of specific, actual and updated health information in destination areas, or not having adequate perceptions regarding travel health risks.

Perceptions towards health risks and preventive measures are important to protect traveler from potential exposure to diseases associated with travel. ${ }^{19,24}$ According to the research results by Kalanlar et.al, although the majority of tourists have a positive perception, only a few of them practice it. ${ }^{18}$ Overall, most backpackers in this study already had positive perceptions regarding the need for prevention, its benefits and the ability to seek health information or advices. However, only $32.32 \%$ received vaccines or received preventive medicines before leaving. This result was similar to that the previous study, where only $34 \%$ of tourists were vaccinated before leaving. ${ }^{19}$

This study showed that backpackers visiting Bali have less health awareness, because most backpackers stated that they were not vulnerable to being exposed to health risks at their destination. More than a third of backpackers were unaware of the need to seek health information. A low perception of the risk of disease infection at the destination was also found among tourists from Egypt studied by El-Ghitany et.al, where $47.50 \%$ felt they were not susceptible to health risks at destination countries. ${ }^{19}$ A research in Turkey, found that $27 \%$ of travelers did not consider that they need to seek health information/consultation before traveling. ${ }^{18}$ 
The findings of this study emphasize that it is necessary to increase backpacker knowledge and awareness regarding travel health. One potential opportunity to strive health promotion to target backpackers is by providing health information media through internet, because it is accesible yet relatively inexpensive. ${ }^{5}$ Moreover, backpackers highly relies on internet to obtain general information of destionation and planning their trips. As results in this study, media should be developed by presenting accurate, specific travel health information, covering current and common potential hazards and health risk in Bali, preventive measures before and during traveling and the travel health services available at destination. ${ }^{17}$ This is in accordance with the recommendations of the World Health Organization (WHO) which states the need for health development through digital interventions, reaching target populations through the provision of health information and health education. ${ }^{25}$ This could be the opportunity for destination country to provide digital health information to ensure health and safety of all visitors and local community.

Furthermore, increasing number of last-minute travelers (arranging trips less than 2 weeks) should be a concern, as they might immediately need accessible travel health information or health services locations at destination. ${ }^{19}$ Thus, based on results of this study, media should be disseminated widely at strategic location (i.e. airports, harbours, bus stations and any types of accomodations), to reach out large number of backpackers who especially visit Bali. For instance, it could also advertised or linked online at Bali tourism websites, embassy or immigration websites, accomodations websites and airline websites to catch out backpackers attentions. ${ }^{5}$

This study has some limitations. This research was conducted in a certain period of time, which may not represent the whole conditions and characteristics of the overall backpackers, such as those who visited Bali in other periods of time. Recruitment of the participants, which was using a non-probability technique, might subject to selection bias. Backpackers who were already concerns with health, would be more likely to took participation in this study than those who were less concerns (self-selection). We approached backpackers in broad and differents sites, various days and times at study locations, and recruited only one backpacker from a same group, these were to ensure diversity to reduce potential selection bias. Information bias might possibly arose since data were derived from self-administered questionnaire, but should not be a high issue in this study. Since our study was not asking highly sensitive topics and we had guaranteed anonymity and confidentiality at the time of data collection, thus respondens answered per their real experiences. In addition, the time of recall period was not too long, and travellers were more likely remember their preparation before a big journey.

\section{Conclusion}

Backpackers' knowledge regarding health risks at travel destination was inadequate, especially regarding most common diseases and health problems faced by tourists in Bali. The 
majority has positive perceptions, but there were some of those who still felt they were not susceptible to diseases and did not realize that they have to seek health information before traveling. Thus, it is necessary to provide an advance health information media. Authorities could develop an innovative web-based or application-based, well-structured, destination-specific, accurate and up-to-date health information and travel health services in Bali. In addition, that media should be disseminated broadly; published offline or linked online to important organisations or hospitality service websites. Although this study was conducted before the pandemic, these findings have implications for tourism both now and in the future. This strategy would not only be applied to address the common health risk or endemic diseases at destination, but also could be used to share information for COVID-19 control.

\section{Acknowledgement}

We would like to thank all respondents who gave their valuable time to take part in our study. We also would like to thank all enumerators who collecting the data and districts and locals authorities for permission to conduct the study in their areas.

\section{Funding}

This study funded by Research and Community Service Unit, Faculty of Medicine, Universitas Udayana (Grant Number 42/UN14.2/LITBANG/2017). The support was merely on funding and was no intervention to the design of study, data collection, analyses, interpretation and conclusion of this study.

\section{Conflict of Interest}

The authors declare that they have no conflict of interest.

\section{References}

1. Glaesser D, Kester J, Paulose H, Alizadeh A, Valentin B. Global travel patterns: an overview. Journal of Travel Medicine. 2017;24(4). Available from: https://doi.org/10.1093/jtm/tax007 [Accessed 12/10/2020].

2. BPS. Number of foreign travellers to Indonesia by nationality 2011-2016. Available from: http://www.bps.go.id/indicator/16/1821/1/jumlah-kunjungan-wisatawan-mancanegara-keindonesia-menurut-kebangsaan.html [Accessed 15th March 2021].

3. BPS. Number of foreign traveller directly come to Bali by nationality 2014-2019 Available from: https://bali.bps.go.id/statictable/2018/02/09/27/jumlah-wisatawan-mancanegara-yangdatang-langsung-ke-bali-menurut-kebangsaan-2014-2018.html [Accessed 15th March 2021]. 
4. WHO. International travel and health. Geneva, Switzerland: World Health Organization; 2012. Available from: http://www.who.int/publications/i/item/9789241580472 [Accessed 15th March 2021].

5. Thomson CA, Gibbs RA, Giele C, Firth MJ, Effler PV. Health seeking behaviours and knowledge of infectious disease risks in Western Australian travellers to Southeast Asian destinations: an airport survey. Tropical medicine and infectious disease. 2016;1(1):3. Available from: https://pubmed.ncbi.nlm.nih.gov/30270854 [Accessed 16th March 2021].

6. Vilkman K, Pakkanen SH, Lääveri T, Siikamäki H, Kantele A. Travelers' health problems and behavior: prospective study with post-travel follow-up. BMC Infectious Diseases. 2016;16(1):328. Available from: https://doi.org/10.1186/s12879-016-1682-0 [Accessed 16th March 2021].

7. Choe Y-J, Choe S-A, Cho S-I. Importation of travel-related infectious diseases is increasing in South Korea: An analysis of salmonellosis, shigellosis, malaria, and dengue surveillance data. Travel Medicine and Infectious Disease. 2017;19:22-27. Available from: https://www.sciencedirect.com/science/article/pii/S1477893917301527 [Accessed 12th April 2021].

8. Frew G, McGeorge E, Grant S, de Wildt G. Hepatitis B: A cross-sectional survey of knowledge, attitudes and practices amongst backpackers in Thailand. Travel Medicine and Infectious Disease. 2017;15:57-62. Available from: http://www.sciencedirect.com/ science/article/pii/S1477893916301818 [Accessed 16th March 2021].

9. Kelly C. The SAGE international encyclopedia of travel and tourism: Thousand Oaks SAGE Publications, Inc; 2017. Available from: https://sk.sagepub.com/reference/the-sageinternational-encyclopedia-of-travel-and-tourism [Accessed 15th March 2021].

10. Heywood AE, Watkins RE, Iamsirithaworn S, Nilvarangkul K, MacIntyre CR. A crosssectional study of pre-travel health-seeking practices among travelers departing Sydney and Bangkok airports. BMC Public Health. 2012;12:321. Available from: https://pubmed.ncbi.nlm.nih.gov/22550996/ [Accessed 19th November 2017].

11. Al-Abri SS, Abdel-Hady DM, Al-Abaidani IS. Knowledge, attitudes, and practices regarding travel health among Muscat International Airport travelers in Oman: Identifying the gaps and addressing the challenges. J Epidemiol Glob Health. 2016;6(2):67-75. Available from: https://www.sciencedirect.com/science/article/pii/S2210600615301234 [Accessed 19th November 2017].

12. Manik G, Suwena IK, Suardana IW. Factor attracting foreign backpacker visiting Bali. Jurnal IPTA (Industri Perjalanan Wisata). 2016;4(2). Available from: https://ocs.unud.ac.id/index.php/pariwisata/article/view/26981 [Accessed 16th March 2021]. 
13. Hatz C, Bühler S, Farnham A. The COVID-19 pandemic offers a key moment to reflect on travel medicine practice. Journal of Travel Medicine. 2020;27(8). Available from: https://doi.org/10.1093/jtm/taaa149 [Accessed 3rd June 2021].

14. Wirawan IMA, Wirawan DN, Kurniasari NMD, Merati KTP. Travel agent and tour guide perceptions on travel health promotion in Bali. Health Promotion International. 2020;35(1):e43-e50. Available from: https://doi.org/10.1093/heapro/day119 [Accessed 16th March 2021].

15. Mansanguan C, Matsee W, Petchprapakorn P, Kuhakasemsin N, Chinnarat N, Olanwijitwong J, Piyaphanee W. Health problems and health care seeking behavior among adult backpackers while traveling in Thailand. Tropical diseases, travel medicine and vaccines. 2016;2:9-9. Available from: https://pubmed.ncbi.nlm.nih.gov/28883953 [Accessed 10th December 2020].

16. Olanwijitwong J, Piyaphanee W, Poovorawan K, Lawpoolsri S, Chanthavanich P, Wichainprasast $\mathrm{P}$, Tantawichien $\mathrm{T}$. Health problems among Thai tourists returning from India. Journal of Travel Medicine. 2017;24(4). Available from: https://doi.org/10.1093/jtm/tax013 [Accessed 16th March 2021].

17. Chen LH, Hochberg NS. Chapter 2 preparing international travelers: the pretravel consultation. New York: Oxford University Press; 2020. Available from: https://wwwnc.cdc.gov/travel/yellowbook/2020/preparing-international-travelers/thepretravel-consultation [Accessed 10th April 2021].

18. Kalanlar B, Şenel M, Gürsel ET, Gönül N, Bilgiç B, Aydoğan FK, Kan O. International travelers' behaviors and knowledge of travel health, travel-related diseases, and vaccinations: a cross-sectional study. International Journal of Travel Medicine and Global Health. 2018;6(4):168-173. Available from: http://www.ijtmgh.com/article_81463.html [Accessed 3rd March 2021].

19. El-Ghitany EM, Abdelmohsen M, Farghaly AG, Abd El-Gawwad E, Abd El-Wahab EW. Travel health survey: risk perception, health-seeking behavior, and subjective evaluation of travel health services in Egypt. International Journal of Travel Medicine and Global Health. 2018;6(1):16-24. Available from: http://www.ijtmgh.com/article_57734.html [Accessed 15th March 2021].

20. WHO. Chapter 6: vaccine-preventable diseases and vaccines. Switzerland: World Health Organisation; 2015. Available from: https://cdn.who.int/media/docs/default-source/traveland-health/9789241580472-eng-chapter-6.pdf?sfvrsn=8c1a400c_14 [Accessed 15th March 2021]. 
21. Adou AA, Napolitano F, Vastola A, Angelillo IF. Travelers' knowledge, attitudes, and behavior related to infectious diseases in Italy. PloS one. 2019;14(4):e0215252-e0215252. Available from: https://pubmed.ncbi.nlm.nih.gov/30978211 [Accessed 16th March 2021].

22. Wirawan IMA, Putri WCWS, Kurniasari NMD, Mulyawan KH, Hendrayana MA, Suharlim C. Geo-mapping of hazards, risks, and travel health services in Bali: results from the first stage of the integrated travel health surveillance and information system at destination (TravHeSID) project. Travel Medicine and Infectious Disease. 2020;37:101698. Available from: http://www.sciencedirect.com/science/article/pii/S1477893920301666 [Accessed 15th March 2021].

23. Subrata M, Purnama SG, Utami AW, Agustina KK, Swacita IBNW. Role of stakeholder in rabies rontrol with integrated one health approach in Bali. Jurnal Kebijakan Kesehatan Indonesia. 2020;9(1). Available from: https://journal.ugm.ac.id/jkki/article/view/54246 [Accessed 16th March 2021].

24. Hiranrusme T, Piyaphanee W, Kaewkungwal J, Silachamroon U, Leowattana W, Chatapat L, Matsee W. Risk perception of health problems among travelers visiting a travel clinic in Bangkok, Thailand. Tropical diseases, travel medicine and vaccines. 2020;6(1):7. Available from: https://doi.org/10.1186/s40794-020-00108-0 [Accessed 10th December 2020].

25. WHO. WHO guideline: recommendations on digital interventions for health system strengthening. Geneva: World Health Organization 2019. Available from: http://www.who.int/reproductivehealth/publications/digital-interventions-health-systemstrengthening/en/ [Accessed 3 March 2021]. 